Potrjeno /

Accepted

22.05.2018

Objavljeno /

Published

21.6.2018

Keywords: architecture; creative reflection; experience interpretation; methods in pedagogy; spatial froms

Ključne besede: arhitektura; ustvarjalna refleksija; doživljajska interpretacija; metode v pedagogiki; oblike prostoa

UDK/UDC

37.091.3:72

\section{Research Probe "My Home”, Artist-BASEd Research / IN SEARCH OF LANGUAGE TO INTERPRET PERCEIVED AND EXPERIENCED SPACE}

Pavla Gajdošíková

${ }^{1}$ Charles University, Faculty of Education, Czeck Republik

\author{
CORRESPONDING AUTHOR/KORESPONDENČNI AVTOR \\ pagajdosikova@gmail.com
}

\begin{abstract}
Povzetek In the research probe "My Home," we investigated students' statements about and how they experience their relationship to a particular place: home. The subject of this exploration is the mutual overlap among architecture, works of art and art education, and their common language across these fields.

The character of our research was inspired by phenomenological approaches. We chose methodologies related to art and design creation. We arrived at the conclusion that the phenomenology of architecture investigated in connection with the semiotic concept of art education can yield much inspiration and is a topic relevant to both the teaching artist and students.
\end{abstract}

\section{Raziskovalna sonda “Moj dom”, Na umetniku temelječa raziskava / Iskanje jezika za interpretacijo zaznanega in doživetega prostora}

$\mathrm{V}$ raziskovalni sondi "Moj dom" smo raziskovali izjave študentov in kako doživljajo svoj odnos do določenega prostora - doma. Predmet tega proučevanja so vzajemna prekrivanja arhitekture, umetniških del in likovne vzgoje ter njim skupen jezik na teh področjih.

Značaj naše raziskave je bil navdahnjen s fenomenološkim pristopom. Izbirali smo metodologije povezane $z$ likovnim in oblikovalskim ustvarjanjem. Prišli smo do sklepa, da fenomenologija arhitekture, ki jo proučujemo $\mathrm{v}$ povezavi $\mathrm{s}$ semiotskim konceptom vzgoje in izobraževanja, daje mnogo inspiracije in je relevantna tema tako za umetnika, ki poučuje, kot za študente. 


\section{Introduction}

The Research Project

\section{Basic characteristics and project objectives}

The Project "Phenomenon of Architecture and Its Pedagogical Implications" forms part of the ongoing outcomes of doctoral studies at the Department of Arts, Charles University, in Prague, Czech Republic. Its objective is to investigate this phenomenon through artistic creation mediated to students and to explore the potential for using findings about the creative processes in educational situations with university students. The Project is based on current public discussions about how architecture influences our apprehension of public space and the quality of life connected with it (Melková, 2013). The topic follows up on the artwork series of the researcher, called Subjective Urbanism.

The Project's points of departure became part of a deeper investigation into how attitudes, values, opinions and their possible changes are structured. It took place at joint sessions of the teaching artist with the students over the topic of apprehending and experiencing architecture and space. The students were invited to participate in co-creation. The resulting documentation became part of a folder containing reflexive evaluation and artistic solution variants. Combinations of specific forms of qualitative and art-based research were exploited in the project (Fulková, 2008). The interpretation of research findings will hopefully become the basis for enhancing the quality of education in the "mediation of architecture" units as part of the art teacher training programs.
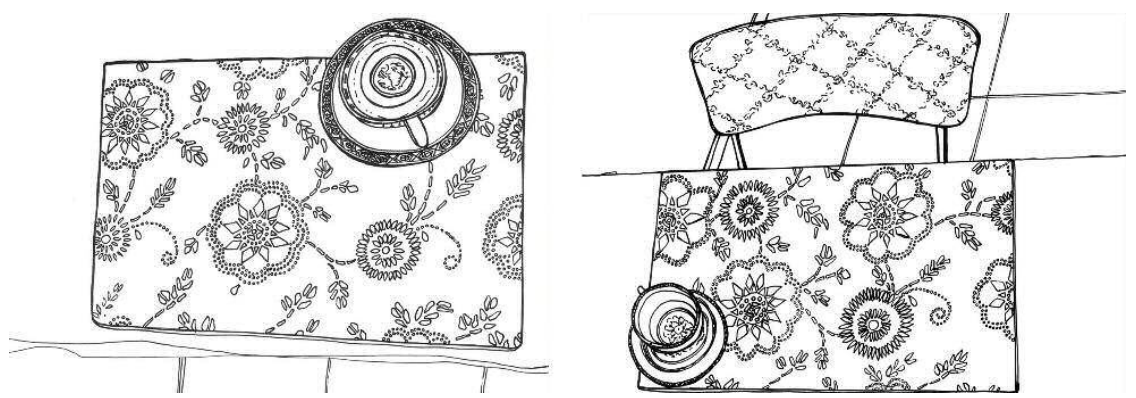

Figure 1: Pavla Gajdošíková, Staring at the Corner, drawings, 2005 - 2018

\section{Project Rationale}

Architecture is an inseparable part not only of our visual world but of human existence, as well. Its content extends to both its utilitarian and artistic functions; it is both respublica (a public affair) and res politica (a political affair). The topic of our relationship to architecture and the environment is currently very timely, yet it is 
not being adequately treated on the society-wide strategic level. Since the 1990s, it has been possible to notice intense discussions in professional periodicals, at conferences and in public life. These discussions seem to suggest that the way of getting architectural concepts across to students should, in principle, involve teaching them how to handle space with competence, since space is in direct relationship to our experiencing the world and finding our identity within it (Kratochvíl, 2015).

A relation to space is essential for human beings, since we cognitively grasp the environment from birth, structuring interpersonal relationships according to basic concepts (Č́íhalová, 2008), even before learning how to speak or to handle other symbolic systems. People spend practically their whole lives in a 'built' environment, which is recognized and constructed vis á vis its opposite, i.e. the open landscape. Perceiving, experiencing and realizing space thus have always played an essential role, which has both subjective and social (cognitive and educational) connotations with economic consequences.

However, the topic of architecture is almost absent from schools and teacher training programs in the field of arts. In our experience, such discussions take place only rarely, not only in elementary and junior high schools, but unfortunately even in secondary schools, colleges and universities.

The necessity of change is called for by, for example, Elisabeth Gaus-Hegner, a German educationalist with long experience of teaching architecture to children, with a focus on art didactics and architecture education; she underpins the necessity of paying attention to this topic from early childhood. According to her findings, it is very important to mediate architecture to children; this means deliberately opening the way for them to experience and get acquainted with space (GausHegner, 2009).

Research Probe "My Home" - Implementation

The Research Probe "My Home" was implemented in October 2017 as a probe of the participatory type at the Faculty of Education, University of Maribor, Slovenia, in cooperation with Tomaž Zupančič, a Slovenian researcher and educator. The probe was part of a workshop called "My Home" (The Place Where I Live). A total of 180 minutes was devoted to it within the framework of art didactics teaching. The sample chosen for the research comprised 11 students, aged 20 to 24 years.

\section{Research - Theoretical Postulates}

In the theoretical postulates, we focus mainly on the semiotic concept of art education. In art education, semiotics is a powerful concept, which can be used to 
revise traditional educational processes; it has a strong impact on the topic and focus of the study, and on the research method itself (Fulková, Tipton, 2008). In this case, the character of our research was inspired by phenomenological approaches, based on the assumption that a phenomenological subject is understood as a "speaking subject" (for instance, a human, a student or "me"). The forms of voices, i.e. their utterances, then exist in close relation with those subjects, who are by their very nature aware of what they say, while simultaneously inviting reflection (Kotzmannová, 2013; Fulková et al., 2013).

We are also interested in the poststructuralist tradition, in a manner similar to that used in the dissertation by Alena Kotzmannová: The Phenomenon of the Sea, Photographs and Description of Sea in Selected Art Forms, which became a starting point for our own research.

In our case, we applied a methodology related to research into artist and designer creation (art-led and practice-based research, or artography) (Irwin, 2004). Specifically, the reflective-practice concept of Donald A. Schön was used for our probe. This approach, which arose from Schön's observations of students of architecture, is a reflection on learning as a tool for gaining knowledge everywhere, where the linear learning model fails and expert knowledge is torn from practice; he also vindicates the implicit, tacit knowledge of practitioners (Schön, 1983).

\section{Research Problem - Research Questions}

The research probe analysis took place in several steps and in the form of response to research questions, which were asked one by one over the course of the research. 1. What are the existing attitudes of both Czech and foreign undergraduate students to architecture and other forms of spatial art?

2. Can these attitudes be changed during joint meetings between the teaching artist and students over the phenomenon / topic of architecture?

3. What are the phenomena on which students focus when perceiving their inner and outer lived space? How do they speak about it, and in what terms? Which phenomena do they mention most frequently?

\section{The topic assigned and workshop progress}

The assigned topic "My Home" (The Place Where I Live) was oriented towards perceiving and realizing space and towards the ability to subsequently conceptualize an artistic solution. We tried to assist students in developing a new artistic sensibility and interdisciplinary creativity, which are often missing from their professional knowledge (Hazuková, 2010). 
In the first part of the workshop, the students became acquainted with the creative portfolio of the artist researcher Pavla Gajdošiková, who tackles the topic of space and architecture in her artwork. After that, the students were invited to discuss and critically reflect upon the artist's work.

The participants were then asked to depict the space of their home, or the place where they lived at the moment, by means of a variety of techniques (drawing or painting). The assigned topic was focused on perceiving and realizing space, and the ability to consequently conceptualize an artistic solution.
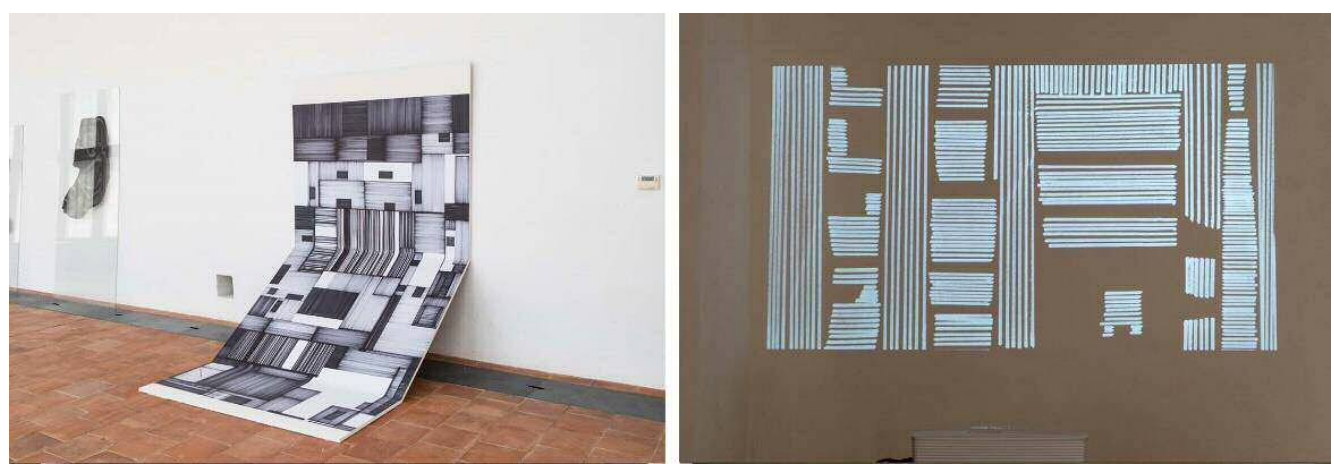

Figure 2: Pavla Gajdošíková, Something Somewhere is Happening, Gallery Entrance, installation view, Prague, 2017

\section{Method of processing the research findings}

The research material that resulted from implementing this probe was subject to a three-step analysis, methodologically based on Schön's concept of reflective practice. Each step (level) of reflection obtained was subject first to open coding, and later to axial coding. Each coding process yielded a list of codes, based on which concept maps were outlined. These maps were further reflected upon and evaluated. All conceptualizations obtained during coding were triangulated (Fulková, 2008; Hendl, 2005).

III. Evaluating reflection on the content and progress of the workshop - research probes

Evaluating reflection from the student viewpoint

We chose both Czech and foreign students for our research probes, to take into account possible differences in apprehending architecture and space in different cultural environments.

In presenting the reflections offered by the students, we would like to call attention to the justification and confirmation of the importance of such research probes 
being done in a chosen foreign environment: "I am glad that the artist comes from another country. It is interesting to listen to people from other countries. The teacher described to us the situation in her environment and how people perceive art there. It was a very interesting lesson. I never thought about my bome in such a context, it was difficult to describe my bouse to somebody else. I thought it would be easy because I know my house and everything is so intimate and familiar, but it turned out to be very hard after all."
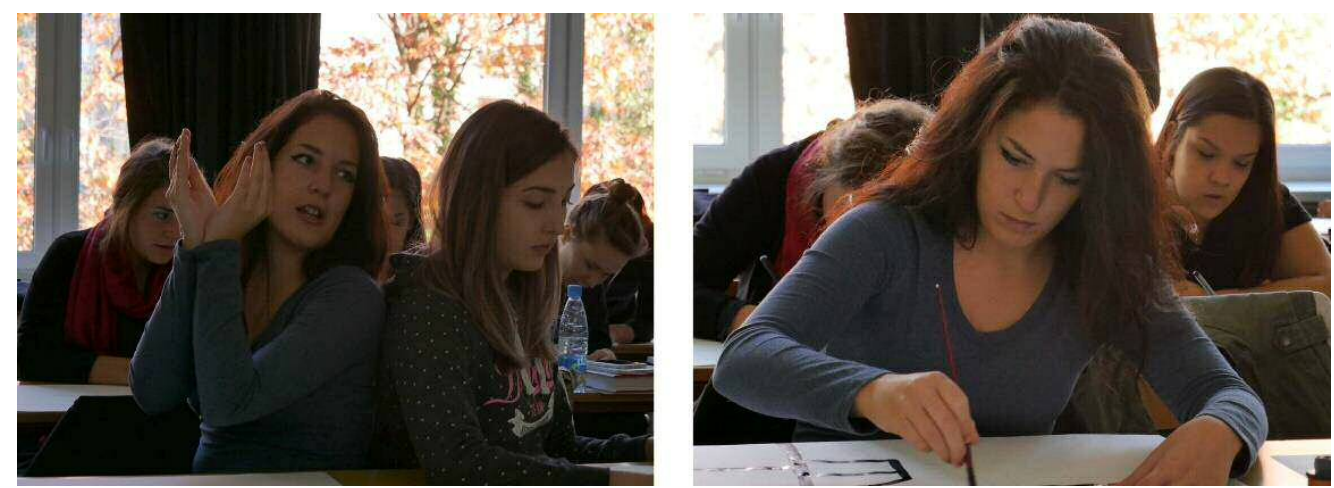

Figure No. 3: Students of the Faculty of Education, University of Maribor during the research probe

What emerges from the students' reflections in the probe is that the topic of architecture and the related topic of apprehending and experiencing space are absent from the local educational system. However, students demonstrated willingness or even eagerness to investigate and explore this topic further, including their interest in the conceptual approach that was employed in this case.

For instance, one of the student participants in the probe stated: "It is a problem in our educational system. We should teach architecture, but unfortunately we do not even mention this topic in the course of our own studies. This topic was very interesting. I believe we should think. about space more often, we sometimes don't even realize where we live. I think this topic is also suitable for children, this method of working in pairs. We worked from a simple sketch on to the final painting."

Evaluating reflection from the viewpoint of art teachers

The authentic content of the students' reflections was confirmed by pedagogical remarks from Tomáž Zupančič, who attended the lessons and highlighted "the students thinking like teachers". 
"Students themselves underlined the need to study space and architecture in their portfolio and art teaching program. In the course of the workshop, the students appreciated the part when they worked in pairs and came up with the idea of utilizing this approach in their teaching practice." We arrived at several findings based on the concept map, which we wish to illustrate by quotations from the author's pedagogical notebook:

"It was interesting for the students to go through the whole process, from chatter to discussion, from experiencing to creating. From conceptual pondering to artistic expression, in this case in the form of drawing and painting. The result was a color picture, which in fact evades direct description of space, but is its colorful representation. It was important for the students to go through the whole process of creation."

The importance of the whole process of the workshop is also expressed in statements by students who went through several stages of artistic perception and expression. "No teacher showed us his or her work like this in the past, neither did they open up to us their way of perceiving and thinking, I very much appreciate that."

"I didn't enjoy this topic much before, but after today's assignment I am starting to reconsider my previous slightly negative thinking about static architecture."
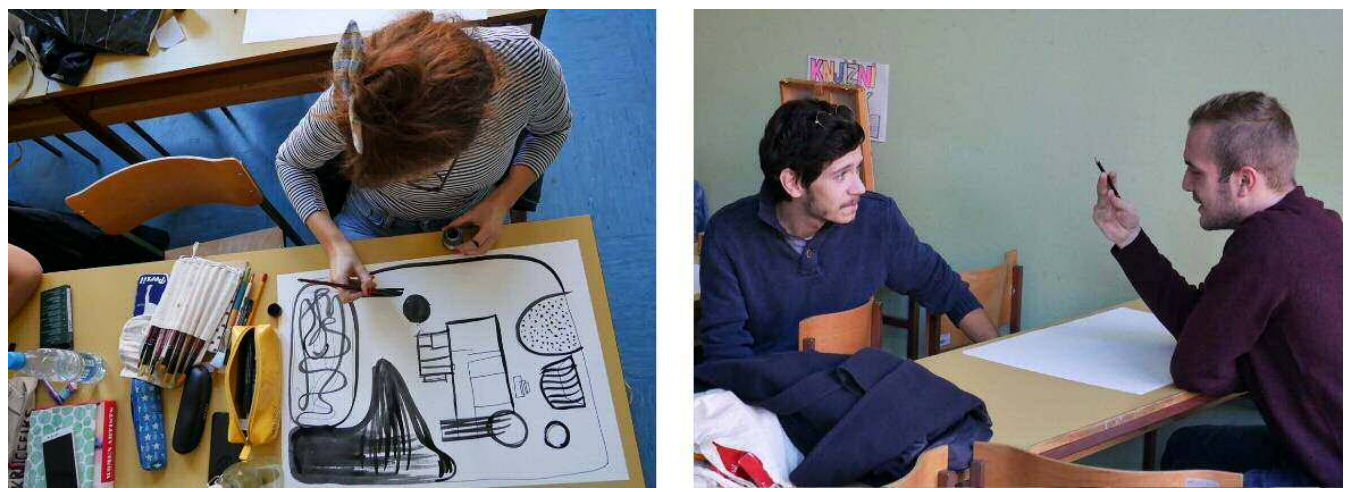

Figure No.4: Students of the Faculty of Education, University of Maribor during the research probe

Concept map analysis

In the concept maps, we analyzed different ways of teaching, forms of teacherstudent cooperation and the potential for their mutual influence. What emerged as essential was the code of the students' attitude to the topic, influenced by the codes of emotion and perception, but also by the theoretical and practical points of departure, used by both students and teacher. Thus, the pedagogical work forms part of these starting points, but at the same time, of individual self-reflection; it is influenced by the artistic and expressive medium. Conceptual thinking is the result of inter-penetration between 
these parts, and can lead to their mutual inspiration, which further influences the work of art itself, and retrospectively also connects to pedagogical work.

\section{First concept map analysis}

Thus, the analysis of the first concept map, which arose after completion of the open coding, again shows the importance of an individual, flexible approach by the teacher to the student, and that the subsequent reflection of the student be accessible to the teacher. What is essential for both the artist and the teacher is that the teacher remain open to new information and impulses coming from the students. This only serves to confirm how important it is to apprehend pedagogical work (Slavík, 2001) and the work of art as a whole, by both students and their teachers.

Another important role was played by language as a medium for transferring information beyond the merely visual. Only in the moment of artwork interpretation or subsequent experiencing by the students does this work surpass the subjectivity border of its creator and become an instrument to be used. On this level, the artwork and architecture approach one another nearly, as do language and its interpretation. Subjective interpretation of the teaching artist experience, but also that of the student, with the work of art, text or actual space--that is what this project strives to follow.

Which reminds us of the idea formulated by L. S. Vygotsky: "Verbal thinking appears to be a complex dynamic whole, in which the relationship between thought and the word is demonstrated as a movement following a whole range of inner planes, and as a transition from one plane to another" (Vygotsky, 2004, p. 129-130). 


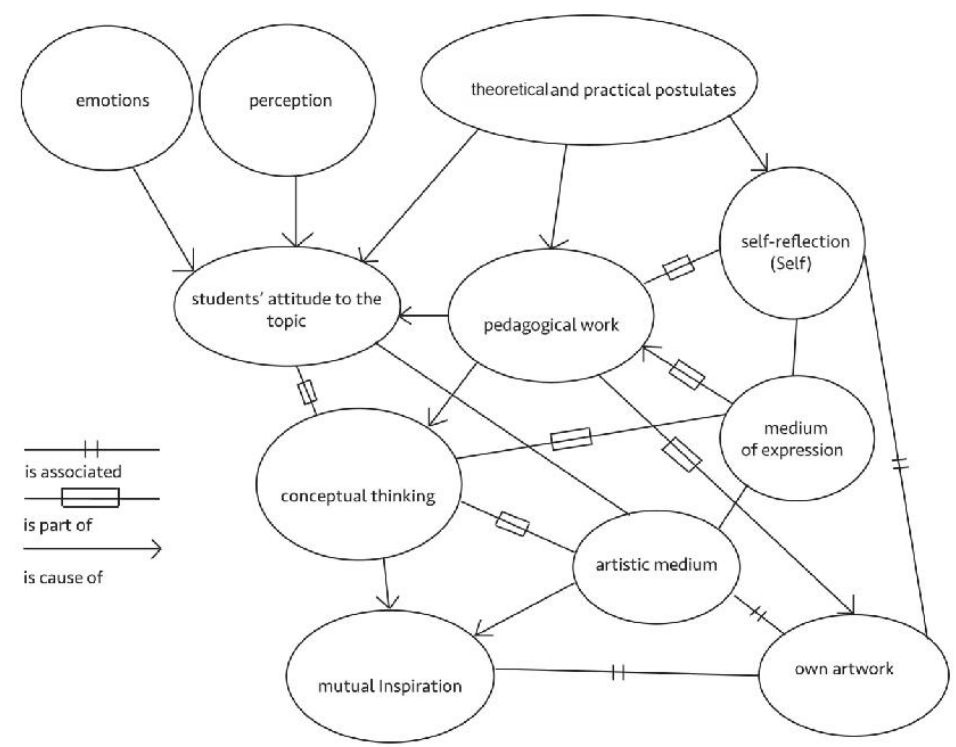

Figure No. 5: Concept map No. 1

\section{Second concept map analysis}

When reflecting on the second concept map, the result of axial coding, we closely analyzed the relation of the students to their topic, which in this case was home, or the place where they lived at the moment. Important codes appeared to be subjectified and objectified space, as agents / factors of perceiving and experiencing lived space.

What is usually understood under "perception" is not just receiving the sensations of perception, or more narrowly only sensations, i.e. certain elementary sensory material, but at the same time a kind of mutual linkage among these, in the form of perceived matter-of-factness. Our perception is influenced not only by what and how we perceive at a given moment, but also by what we have perceived before, i.e. our previous experience. The "space" then once again becomes, in the most common sense, our closest neighborhood surrounding us. The words "neighborhood" and "surrounding" refer to two essential preconditions of a space: that "around" which it finds itself, e.g. the human being in his or her physicality as the center of linkages, and that "which" surrounds man.

What clearly follows from these concept maps is that experiencing the whole process of creation by students and its subsequent reflection leads to conceptual thinking. This important component of contemporary art is what students often lack. Thinking about working with a specific medium and its deliberate usage is part and parcel of any 
conceptual artwork. That is why we, with the help of verbal communication, led the students to conceptual thinking about the topic, and to its visual communication through different artistic media.

Based on analysis of the concept maps, we arrived at findings indicating the dominance of the code of subjectified space. This notion is used by Havel and Mitášová to define space and distinguish the ways of grasping it. To elucidate this notion, we can use a metaphor: the point is who experiences the space, what "bis" space means to him as an individual, what it allows him to do and what it does not allow (Havel, Mitášová, 2004).

This subjectified space is influenced, above all, by the following codes: identification with self, emotions, fragrance, color and light, but also by nature and size.

The students' statements referred to objectified space, which the above authors define as follows: "Here we are rather interested in what is being experienced, i.e. which characteristics belong to space "per se", independent of individual experience" (Havel, Mitášová, 2004, p. 154).

Moreover, the above authors add: "This however is a somewhat artificial distinction between two tendencies, when one or the other can prevail in reflecting on the experienced space; however, they are both present and mutually linked" (Havel, Mitášová, 2004, p. 154). This is why some codes reflect both these spaces. This is the case with nature, size, light, and color.

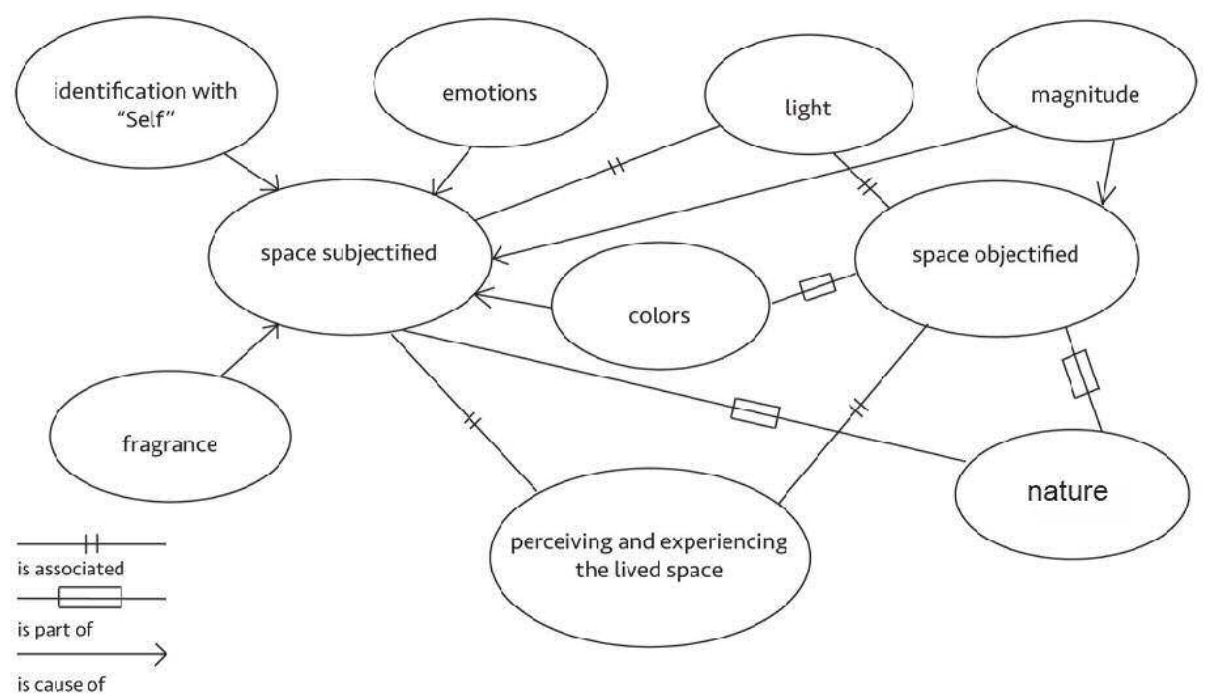

Figure No. 6: Concept map No. 2 
Summary of research probe findings

The research findings have shown that most students consider home to be a pleasant place, connected with relaxation, rest or cooking. They identify with their home through their personality, their "Self": "I love my house. I love everything about it. My room, even though I live somewhere else, is snug and comfortable. It is the place I know best." This experience verified, we can draw the following conclusions:

(1) Home (as architecture or a space) forms in a sense the students' personality and influences them. (2) Home is an important place influencing life and perception of personalities also in other directions. Students thus perceive and experience this space or architecture with much intensity based on their own positive or negative previous experience. It can be taken as proven that our perception affects the way we interpret the world, but also the other way round, that our interpretation of the world affects the way we perceive our place, our home. Thus the criteria of architecture evaluation are connected with this experienced phenomenon.

This assumption of ours is based upon the statement of Hogenová, who deals with phenomenology of home in her several works.

Dwelling saves the Earth. How? It internalizes it. Like springs of grand rivers bringing to surface their beginnings - resources in sensory form, the same way man, by dwelling on it, brings to Earth internalization, which contemplates in the fire of the hearth like the center of the world, which is there for each dweller. Home is the center of the world, which has been quite forgotten. It is the firm point; it is the referent of movement in the sense of rising into form, which also is meaning. (Hogenová, 2013, p. 265)

One of the students had several interesting observations, and what we found most engaging was things he noticed when investigating his own home. They were fragrances and sounds. He described the sound of women's heels he heard in his flat. He was captivated by scents coming from the bathroom in the morning. Let us quote an excerpt from the questionnaire filled in by this participant, which was even slightly critical:

"I perceive space emotionally, through confirming my different specific memories related to individual objects and spaces, which however keep constantly changing. Space influences me. The lesson was interesting for specific reasons, but in fact it did not motivate me much to create something, because I do not really enjoy living in these temporary spaces, which these places in fact are." 

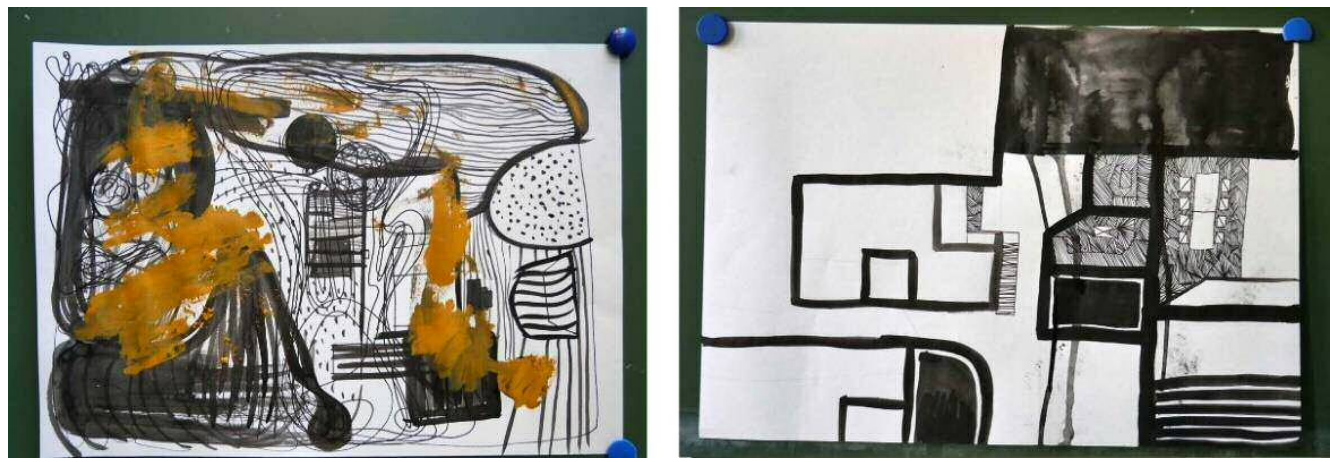

Figure No. 7: Artwork by students from the Faculty of Education, University of Maribor

\section{Conclusion}

The primary assumption of our research team was that neither "architecture" nor "space" was a frequent topic of study for our sample of students, whether as part of their pedagogical activity or in their own artwork. We saw the reason especially in the students' lack of information about and experience with these phenomena. Based on our research probe findings, we arrived at the following conclusion:

If the teaching artist renders this topic in an innovative way and gives the students an idea even by introducing his or her own artwork, the students show a high level of interest. Thus, we conclude that it is important for students (trainee teachers) to experience space and architecture intensely, based on awareness of their subjective experience, as well as having direct contact with the teaching artist. Existing research findings confirm the "presence of pedagogical work and the work of art" as a highly important phenomenon or event in the moment these two co-exist. Richter confirms the idea: "Only a teacher who has personal experience in resolving visual arts problems can articulate teaching units. Motivation that is methodologically and educationally well prepared requires the teaching artist's own practical work in the field" (Richter, 2017, p. 253). This topic is highly relevant and inspiring for both the art teacher and the artist, making it almost a requirement to be dealt with as part of professional practice, thus handing on his or her experience yet further. We arrived at the conclusion that investigating the phenomenology of architecture in connection with the semiotic concept of art education is indispensable for both the teaching artist and the student. We deem it a perpetual task of architecture to create an existential metaphor that gives our being in the world a concrete shape and structure. Architecture reflects upon, materializes and immortalizes ideas and images of an ideal life. Space and our perception of it make us capable of structuring 
and also understanding the shapeless flow of reality and, last but not least, of realizing what we are.
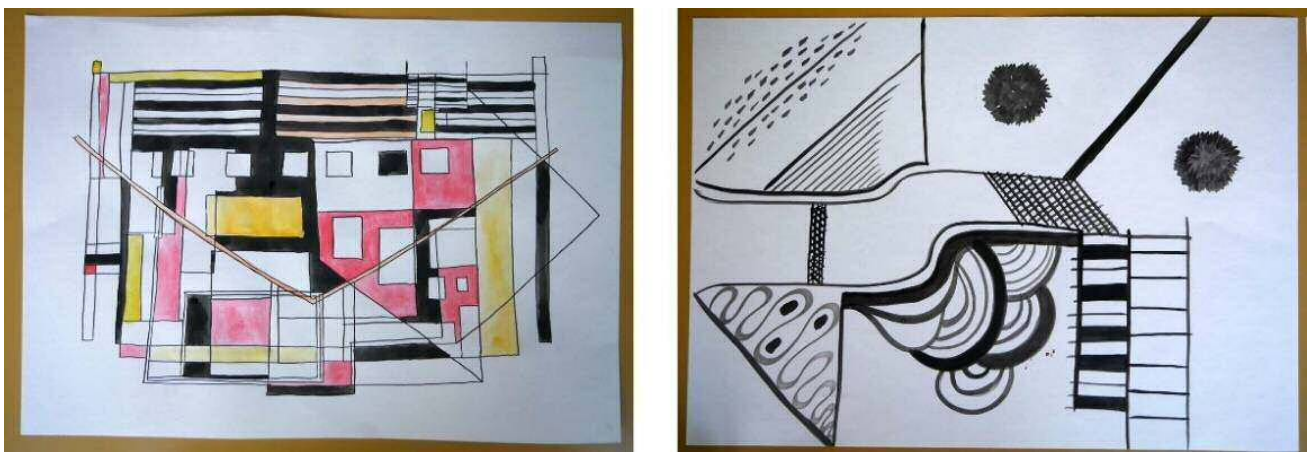

Fig. No. 8: Artwork by students from the Faculty of Education, University of Maribor

What follows each and every experience like this are the actions of remembering, recalling and comparing. Memory plays an essential role as a basis for our recall of space and place. We "redraw" all places we lived, and all spaces we knew, in the embodied memory of our bodies. Our home merges with and grows through our identity, becoming part of our own body and existence (Pallasma, 2012).

There will be a follow-up to the "My Home" research probe, in the form of analysis of two other research probes: "Paths" and "Memory of a Place". The research findings are meant for art teachers and students at teacher training institutions. We see the contribution of our research to art education theory in verifying the functionality of the new methodology in an actual educational environment and with specific findings that can be used in teaching practice.

\section{Summary}

The Project, being part of doctoral studies at the Department of Art Education, Charles University Prague, Czech Republic, has its main focus on knowledge gained through art making in relation to the phenomenon of architecture and the potential for using the research findings about related creative processes in learning situations with university students. The project's content is grounded in the ongoing public discussion about the impact of architecture on the environment and human life. Inspiration for the topic came from the artistic project "Subjective Urbanism", whose basic ideas became part of an intensive investigation into the structure of attitudes, values, opinions and their possible changes in teacher-student sessions on the topic of architecture in the contemporary world. The students were invited to 
participate in co-creation, which was documented and became part of a folder on reflexive valuation and variants of creative solutions. Our research makes use of combinations of specific forms of qualitative and art-based research. Interpretation of these research findings will lead to enhanced quality of lessons on "mediating architecture" in art teacher training programs.

This research probe was part of my doctoral study visit to the Department of Art Education, University of Maribor, Slovenia, and triggered a program of cooperation between post-graduate students and teachers at the two institutions. The probe of participatory type was conducted with students in their $5^{\text {th }}$ year, that is, Master's Degree students (11 students aged $21-24$ years). It took place on $23^{\text {rd }}$ October 2017 as part of instruction in art didactics, and lasted 180 minutes. The topic of the workshop during which the probe was carried out was Architecture / My Home.

\section{References}

Č́halová, M. (2008). The Conditions of Rationality as Reflected from the Standpoint of the Knowing Subject, Philosophy Journal, 56 (5), 921 - 928

Fulková, M. (2008). Diskurs umění a vadeláváni / The Discourse of Art and Education. Jinočany: H \& H Fulková, M., et al. (2013). Murejní a galerijní edukace / Museum and Art Gallery Education 2. Učeni z umèní / Learning from Art. Educational Programs of the Museum of Decorative Arts in Prague and Rudolfinum Art Gallery 2012 and 2013. Prague: Charles University, Faculty of Education and Museum of Decorative Arts in Prague,

Fulková, M, Tipton, T. (2008), A (Con)text for the New Discourse as a Semiotic Praxis. The International Journal of Art and Design Education, 27 (1).

Gaus-Hegner, E. (2009). Raum erfabren - Raum gestalten: Arcbitektur mit Kindern und Jugendlichen, Taschenbuch.

Havel, I. M., Mitášová M. (2004) Prostor prožívaný jako prostor k jednání / Space Experienced as a Room for Negotiation. In: Ajvaz, M., Havel, I. M., Mitášová, M., (Ed). Prostor a jeho clověke / Space and Its Man. (p. 153 - 220), Prague: Vesmír.

Hazuková, H. (2010). Didaktika výtvarné výchory VI / Didactics of Art Education VI. Prague: Charles University, Faculty of Education.

Hendl, J. (2005) Kvalitativni výžkum: základní metody a aplikace / Qualitative Research: Basic Methods and Applications. Prague: Portál

Hogenová, A. (2013). Fenomén domova / The Phenomenon of Home (p. 265), Prague: Charles University, Faculty of Education.

Irwin, R. (2004). A/R/Tography: Rendering Self Through Arts-Based Living Inquiry, Vancouver, Canada: Pacific Educational Press

Kotzmannová, A. (2013). Fenomén moré, Fotografie a popis more ve vybraných formách umèni / The Sea Phenomenon, Photographs and Description of the Sea in Selected Art Forms. Dissertation Thesis.

Prague: Charles University, Faculty of Education

Kratochvíl, P. (2015). Mèstský veréný prostor/ The Urban Public Space. Prague: Zlatý řez.

Melková, P. (2013). Proživat architekturu / Experiencing Architecture. In Řevnice: Arbor vitae.

Pallasma, J. (2012), Oči kůže / The Eyes of the Skin. Zlín: Archa. Richter, M. (2017), Teaching Visual Arts - From Innocent Eye to Immersiveness and Vice 
Versa, Journal of Elementary Education $10 \quad(2 / 3), \quad 253-259$ Schön, D. (1983). Reflective Practitioner. How Professionals Think in Action. New York: Basic Books.

Slavík, J. (2001). Umèni záq̌itku, záz̆itek umèni: teorie a praxe artefiletiky / The Art of Experiencing, Experiencing Art: Theory and Practice of Artefiletics. Prague: Charles University

Vygotsky, L. S. - Průcha, J. (2004). Psychologie myšleni a reči / Psychology of Thought and Speech (p. 129-130) Prague: Portál.

The Research Project Phenomenon of Architecture and Its Educational Implication was supported by the Charles University Grant Agency (GAUK No. 250357) and has been carried out at the Charles University Prague, Faculty of Education.

\section{Author}

\section{Pavla Gajdošíková, MA, PhD student}

Charles University, Faculty of education, Magdalény Rettigové 4, 11639 Prague, Czech Republik, email: pagajdosikova@gmail.com

Doktorska študentka, Karlova univerza, Pedagoška fakulteta, Magdalény Rettigové 4, 11639 Prague, Czech Republik, e-mail: pagajdosikova@gmail.com 